\title{
Highly sensitive optical detection of specific protein in breast cancer cells using microstructured fiber in extremely low sample volume
}

\author{
Saraswathi Padmanabhan \\ Vengalathunadakal K. Shinoj \\ Vadakke M. Murukeshan \\ Nanyang Technological University \\ School of Mechanical and Aerospace Engineering \\ 50 Nanyang Avenue \\ Singapore, 639798
}

\author{
Parasuraman Padmanabhan \\ Singapore Biolmaging Consortium \\ Laboratory of Molecular Imaging \\ 11 Biopolis Way 02-02 Helios \\ Singapore, 138667
}

\begin{abstract}
A simple optical method using hollow-core photonic crystal fiber for protein detection has been described. In this study, estrogen receptor (ER) from a MCF-7 breast carcinoma cell lysates immobilized inside a hollow-core photonic crystal fiber was detected using anti-ER primary antibody with either Alexa ${ }^{\mathrm{TM}}$ Fluor 488 (green fluorescent dye) or 555 (red Fluorescent dye) labeled Goat anti-rabbit IgG as the secondary antibody. The fluorescence fingerprints of the ER $\alpha$ protein were observed under fluorescence microscope, and its optical characteristics were analyzed. The $\mathrm{ER} \alpha$ protein detection by this proposed method is based on immuno binding from sample volume as low as $50 \mathrm{~nL}$. This method is expected to offer great potential as a biosensor for medical diagnostics and therapeutics applications. () 2010 Society of Photo-Optical Instrumentation Engineers. [DOI: 10.1117/1.3302810]
\end{abstract}

Keywords: fiber optic sensor; photonic crystal fiber; MCF-7 cells; protein immobilization; estrogen receptor; fluorescence imaging and sensing.

Paper 09063R received Feb. 23, 2009; revised manuscript received Sep. 14, 2009 ; accepted for publication Nov. 30, 2009; published online Feb. 16, 2010.

\section{Introduction}

Biomedical research is mainly focused on detection, diagnosis, treatment, and prevention of diseases that ultimately leads to better health. Ultrasensitive detection and imaging methods are enabling technologies for the improvement of the same to take the arena of diagnostics methodologies to the next level. The steady advancement of biology and medicine toward diagnostics based on molecular markers leads to the exploration of high-throughput methods for the detection of biomolecules and their interactions in a biological system. Protein microarrays are an imperative tool for proteomics research and are also used in biomedical applications to determine the presence and/or amount of proteins in a biological sample. ${ }^{1}$ In recent years, fluorescence assay technologies have played a pivotal role in the high-throughput analysis of proteins and protein interactions. The precise measurement of a fluorescence signal is a critical parameter in analyzing the functional response of the biological sample. ${ }^{2}$ Fluorescence-based bioassays are novel diagnostic tools to the clinicians for deciding on further treatment and to the researchers for monitoring biological functions that lead to novel investigations. Detection at the molecular level, such as reporter assays and gene expression studies, are achieved by improved techniques using fluorescent proteins as biomarkers.

A nanotechnology-based platform offers promise for multiplexed detection of proteins and nucleic acids to bring substantial advances in molecular medicine. A broad spectrum of highly innovative approaches of nanodevices was critically

Address all correspondence to: Parasuraman Padmanabhan, Singapore Biolmaging Consortium, Laboratory of Molecular Imaging, 11 Biopolis Way 02-02 Helios, Singapore, 138667. Tel: (65) 6478 8728; Fax: (65) 6478 9957; E-mail: padmanabhan@sbic.a-star.edu.sg reviewed. ${ }^{4}$ These include surface nanotexturing for mass spectrophotometry and reverse phase protein microarrays, the biobar code assay, biologically gated nanowire sensors, and silicon-based nanostructures for the transduction of molecular binding in to an electrical and a mechanical signal, respectively. Recent progress of optical fiber-based biosensors and their sensing performances have found good potential and were elaborately reviewed in the literature. ${ }^{5}$

Photonic crystal fibers (PCFs) are a special class of silicabased microstructured optical fibers (MOFs) with tiny air holes running along the length of a silica fiber. ${ }^{6}$ Among them, hollow-core PCF (HC-PCF) can achieve air guiding and can be used for efficient biosensing application due to the increased light-matter interaction in the $\mathrm{HC}^{7}$ These fibers has been used for evanescent wave sensing or highly efficient sensing of biomolecules, such as DNA, enzymes, antigen, antibodies, and proteins. ${ }^{8-12}$ Hence, these HC-PCFs can be used as "immobilization nanoholes" and it has been proven that photonic bandgap can be preserved by filling the center core with the solution and, thereby, making it an ideal probe for sensing applications. ${ }^{13}$

Breast cancer is the fifth most common cancer, which leads to 502,000 deaths worldwide per year, and it has already been linked with the steroid hormone estrogen. ${ }^{14}$ It has long been known that many human breast cancers are initially hormone dependent, which has led to the utilization of antiestrogens in the treatment of breast cancer. ${ }^{15,16}$ Discovery of the estrogen receptor (ER) has given insight, not only as a powerful diagnostic and predictive marker, but also as a proficient target for the treatment of hormone-dependent breast cancer. ${ }^{17,18} \mathrm{Sev}$ eral techniques are available for the specific detection of the

1083-3668/2010/15(1)/017005/6/\$25.00 ○ 2010 SPIE 
said protein. The immunosensing technique is a powerful and flexible tool, used to identify targeted an antigen with desired specific antibodies. ${ }^{19-21}$ Even though enzyme-linked immunosorbent assay (ELISA) is an old method, it still in use to detect proteins, ${ }^{22,23}$ but it has the disadvantage of showing nonspecific interaction leading to false positives. The gel shift assay is another approach for detecting the ER protein; its intracellular localization and expression levels are reported elsewhere. ${ }^{24}$ This assay needs a precise radioactive tracer and a specific protected area with federal certification approval and supervision. Immunohistochemistry (IHC) is another technique for assessing the ER status of breast cancers. ${ }^{25,26}$ It has a repeated disadvantage in deciding the level of expression, the Allred's IHC score between 2 and 3. In this context, we have made an approach to develop a technique to detect the $\operatorname{ER} \alpha$ protein. This method is mainly proposed and illustrated using a HC photonic crystal fiber based on immunobinding, which can be an efficient biosensor in clinical diagnosis.

\section{Materials and Methods}

The ER-positive MCF-7 Breast carcinoma cells and ERnegative MDA-MB 231 cells were chosen for the study.

\subsection{Cell Culture and Sample Preparation}

Both MCF-7 and MDA-MB 231 cells were grown to confluence in Dulbecco's modified-eagle-medium-high glucose supplemented with $10 \%$ fetal bovine serum and $1 \%$ penicillin and streptomycin. The media were removed from the 12 well culture plates in which the cells were grown, and the cells were washed twice with phosphate buffered saline (PBS). These cells were lysed $(200 \mu \mathrm{L})$ in lysis buffer $(1 \mathrm{X})$, kept at $4{ }^{\circ} \mathrm{C}$ rotator for $1 \mathrm{~h}$. After incubation, $5 \mu \mathrm{L}$ of $200 \mathrm{mM}$ phenylmethylsulfonyl fluoride was added and centrifuged at $10,000 \mathrm{rpm}$ for $15 \mathrm{~min}$. The supernatant-containing protein was extracted and stored at $-70{ }^{\circ} \mathrm{C}$ until use.

\subsection{Western Blot Analysis Using Anti-ER Antibody}

The concentration of proteins in the cell lysates were quantified using the Bradford method. ${ }^{27}$

The endogenous estrogen receptor levels in the positive cells were detected using the antibody raised against $\operatorname{ER} \alpha$. For this purpose, $10 \mu \mathrm{g}$ protein was resolved by $4-12 \%$ gradient sodium dodecyl sulfate-polyacrylamide gel electrophoresis and was transferred to nitrocellulose membrane. The membrane was blocked in $1 \mathrm{X}$ Tris buffered saline with tween-20 (TBST) containing 5\% milk powder for $3 \mathrm{~h}$. The membrane was further incubated overnight in the same buffer containing anti-ER $\alpha$ antibody (Acris Antibodies, GmbH, Germany) at $4{ }^{\circ} \mathrm{C}$. The membrane was washed and incubated with the secondary anti-Rabbit antibody conjugated with horseradish peroxidase (HRP) enzyme for $2 \mathrm{~h}$. The washed membrane was incubated with chemiluminescent substrate for HRP and exposed to X-ray film and developed. The stripped membrane was detected for protein $\beta$-actin and used as internal loading control.

\subsection{ELISA}

The same crude extracts protein and antibody (Acris Antibodies $\mathrm{GmbH}$, Germany) were used to perform ELISA. The

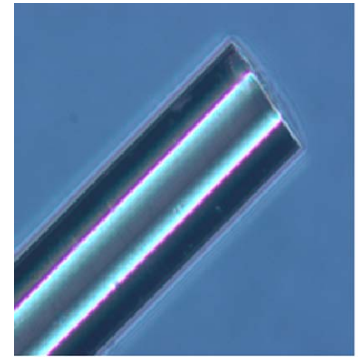

(a)

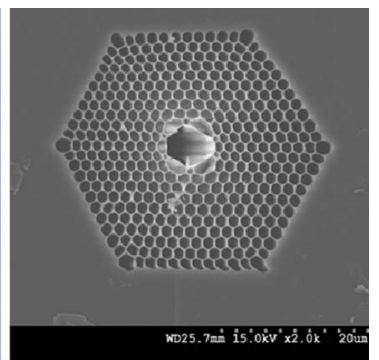

(b)
Fig. 1 (a) Scanning electron microscope image showing the cross section of the fiber core and (b) end facet of the photonic crystal fiber under a microscope.

protein was diluted to $0.001 \mu \mathrm{g} / 25 \mu \mathrm{L} \quad(1 \mathrm{ng})$, $0.005 \mu \mathrm{g} / 25 \mu \mathrm{L} \quad(5 \mathrm{ng}), \quad 0.02 \mu \mathrm{g} / 25 \mu \mathrm{L} \quad(20 \mathrm{ng})$, $0.04 \mu \mathrm{g} / 25 \mu \mathrm{L}(40 \mathrm{ng})$, and $0.05 \mu \mathrm{g} / 25 \mu \mathrm{L}$ (50 ng) in coating buffer (0.1 $\mathrm{M} \mathrm{NaHCO}_{3}, \mathrm{pH}$ 8.6). Twenty-five microliters of each diluted protein was added to each well of a pretreated ELISA plate, and it was then covered with plastic film and incubated at $4{ }^{\circ} \mathrm{C}$ overnight. The wells were blocked by adding $50 \mu \mathrm{L}$ of $3 \%$ bovine serum albumin (BSA)/PBS and incubated for $1 \mathrm{~h}$ at $37^{\circ} \mathrm{C}$ in a moist, sealed container. Then $25 \mu \mathrm{L}$ of $1 \%$ BSA/PBS mixed with primary antibody was added to each well. The plates were shacked well with the antibody solution and washed with $1 \mathrm{X}$ PBS/Tween 20 $(0.05 \%)$. Antibody enzyme conjugates (antimouse alkaline phosphatase at 1:1000 in 1\% BSA/PBS) was added $(25 \mu \mathrm{L})$ to each well and again incubated at $37^{\circ} \mathrm{C}$ for $1 \mathrm{~h}$. Again, each well was washed with $1 \mathrm{X}$ PBS/Tween 20 (0.05\%). Finally, $50 \mu \mathrm{L}$ of substrate solution (one tablet of Sigma $104^{\circledR}$ phosphatase in $5 \mathrm{~mL}$ alkaline phosphatase developing buffer) was added to each well. The developed color was read at 15 , 30 , and $60 \mathrm{~min}$, respectively.

\section{Implementation and Experimental Analysis}

\subsection{Photonic Crystal Fiber}

HC photonic crystal fiber was chosen for this sensor development (Crystal Fiber A/S-AIR-6-800). The fiber was cut into segments of $\approx 10 \mathrm{~cm}$ length, and one end of the fiber was cleaved approximately into $1.5-2.0 \mathrm{~cm}$ length [Fig. 1(a)]. This fiber has a center core size of diameter $6 \pm 1 \mu \mathrm{m}$ and cladding diameter of $122 \pm 5 \mu \mathrm{m}$ [Fig. 1(b)].

\subsection{Protein Immobilization}

The different steps involved in the process were schematically represented in Fig. 2. The tip of the fiber was dipped in the $0.01 \%$ Poly L-lysine (Sigma Aldrich, USA) solution for $3 \mathrm{~min}$, and the solution is allowed to get into the fiber by simple capillary forces. The fiber was permitted to dry out at room temperature for $\sim 1 \mathrm{~h}$. After drying, it was washed twice with PBS for $5 \mathrm{~min}$; thus, the inner core was activated for further process. Then, the cell lysate solutions from MCF-7 and MDA-MB-231 were immobilized separately into different fibers for protein binding $(3 \mathrm{~min})$. After that, the fibers were incubated at $4{ }^{\circ} \mathrm{C}$ for $2 \mathrm{~h}$ then washed thrice briefly in TBST buffer. 


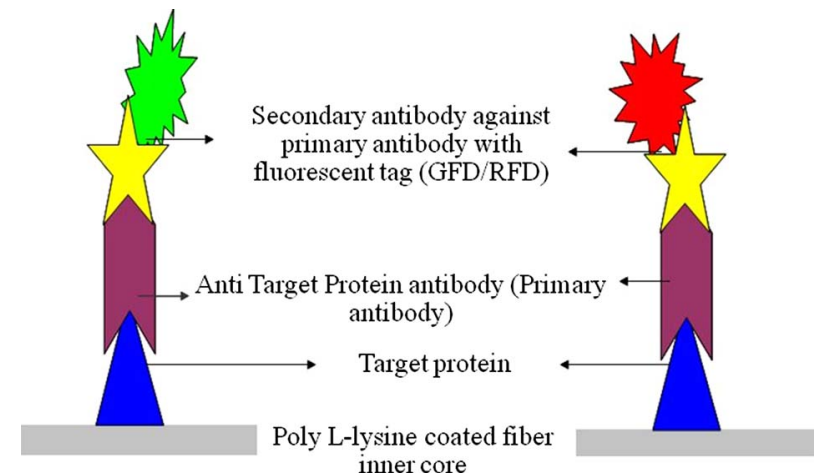

Fig. 2 Cartoon showing specific protein binding by developed protocol.

In the next step, the primary antibody binding was done using antiestrogen $\alpha$ [primary antibody (Acris antibodies, $\mathrm{GmbH}$, Germany)] solution diluted to a final concentration of 1:1000 (1-4 $\mathrm{mg} / \mathrm{mL})$ in TBS for 5-10 $\mathrm{min}$ and incubated for $3 \mathrm{~h}$ at $4{ }^{\circ} \mathrm{C}$. Concurrently, sodium iodide symporter antibody (primary antibody; Whatman ${ }^{\circledR}$ ) was also used to check the nonspecific binding of the $\operatorname{ER} \alpha$ protein. Then the fibers were washed with TBST buffer (thrice) for $10 \mathrm{~min}$ and dried at $4{ }^{\circ} \mathrm{C}$ for $1 \mathrm{~h}$. The experiment was completed by adding a secondary antibody solution made in TBS containing Alexa ${ }^{\text {TM }}$ Fluor 488 (green fluorescent dye) or 555 (red fluorescent dye) labeled Goat anti-rabbit IgG Invitrogen ${ }^{\mathrm{TM}}$ diluted to $1: 100$, the same way as that of the earlier step. Appropriate controls were performed simultaneously for both green/red dye detection. Now the immuno binding of the protein was completed and the fibers were ready for imaging sensing. The fibers were stored in dark ambience at $4{ }^{\circ} \mathrm{C}$.

\subsection{Imaging and Sensing Analysis}

The cleaved end of the fiber carrying immobilized protein was focused under the microscope (Olympus fluorescence microscope CKX41) and checked for the fluorescence signal. The schematic setup used for the spectral analysis of fluorescent proteins was shown in Fig. 3. For fluorescence analysis, diode pumped solid state (DPSS) laser (output power $10 \mathrm{~mW}$ ) was coupled to the proximal end of the HC photonic crystal fiber. The beam emerging from the distal end of the fiber was focused to a high-quantum-efficiency spectrophotometer (Ocean Optics, QE65000) using a microscope objective $(20 \times$, $0.65 \mathrm{NA})$. In this study, lasers with wavelength of 473 and $532 \mathrm{~nm}$ were used for the analysis of green fluorescent dye and red fluorescent dye, respectively.

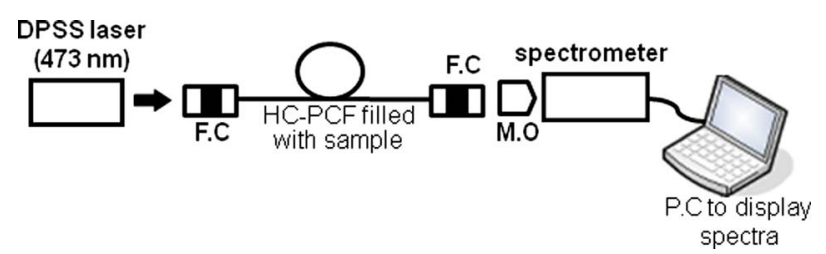

Fig. 3 Schematic diagram. Experimental setup used for the spectral analysis: DPSS laser; MO, microscope objective; FC, fiber coupler; and HC-PCF, hollow core-photonic crystal fiber.

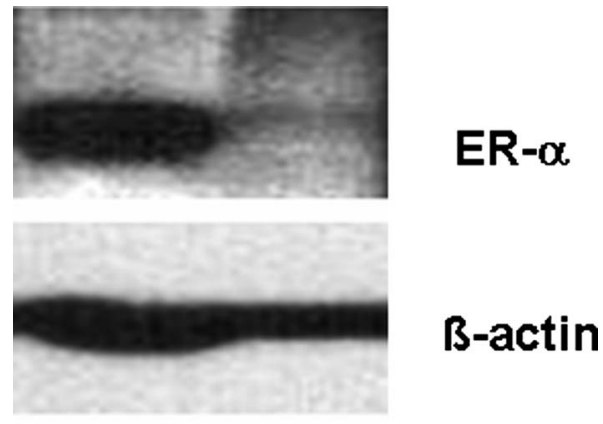

(a)

(b)

Fig. 4 Western blot analysis for cellular ER, $\beta$-actin to confirm the ER-basal level of ER- $\alpha$ in (a) MCF-7 (ER-positive) and (b) MDA-MB231 (ER-negative) cells. $\beta$-actin act as a protein internal standard.

\section{Results}

\subsection{Protein Concentration and Western Blot Analysis}

The estimated amount of protein in MCF-7 and MDA-MB231 cell lysates by Bradford's method is found to be $1 \mu \mathrm{g} / \mu \mathrm{L}$. The amounts of ER $\alpha$ protein immobilized in the fibers were calculated according to the protein quantity in the cell lysate. To confirm the ER protein signal, the cells are analyzed for Western blot using anti-ER $\alpha$ antibody for cellular ER, and anti- $\beta$-actin antibody for $\beta$-actin. The result obtained is positive in the MCF-7 cells and negative in the MDA-MB-231 cells. This is the qualitative confirmation for the presence of ER protein in two different cells (Fig. 4). Because the $\beta$-actin is the housekeeping gene, it gives a signal in both cell lines, whereas the negative cell line MDAMB-231 has failed to produce a signal due to lack of a receptor.

\subsection{ELISA Assay}

Among the different concentrations of samples used, a positive signal is observed in $50 \mathrm{ng}$ of protein by the ELISA technique, whereas the detection failed in 1, 5, 20, and $40 \mathrm{ng}$ of protein. This shows the significance of the results obtained with PCF, where only $\sim 20$ pg protein is needed for obtaining the positive signal, whereas several fold more protein is needed for the detection through ELISA.

\subsection{Fluorescence Analysis}

The green and the red signals from the fiber imaged under the microscope are shown in Figs. 5(a)-5(d) and 6(a)-6(d), respectively. The fluorescent signal is found to increase linearly with the concentration of cell lysate as a result of a greater number of binding surfaces inside. The protein binding inside the fiber is further confirmed by spectroscopic analysis. Both the control fibers MDA MB 231 and the sample fiber MCF-7 are analyzed for the emission signal. The control fibers (MDA-MB-231) showed no emission peak, whereas a greendye emission is observed in MCF-7 fibers at $515 \mathrm{~nm}$, as given in Figs. 7(a) and 7(b) and a red dye emission around $585 \mathrm{~nm}$ as given in Figs. 8(a) and 8(b). These spectral signatures authenticate the strong binding of $\operatorname{ER} \alpha$ protein inside the photonic crystal fiber. 

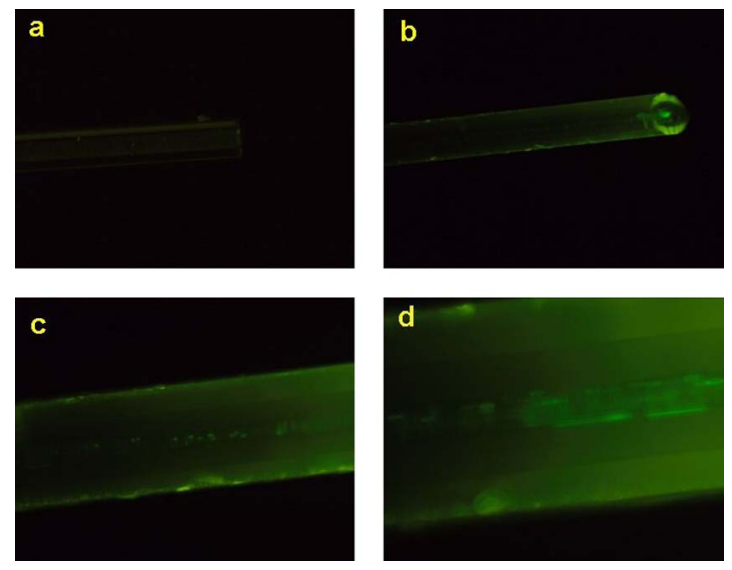

Fig. 5 Fluorescent microscopic images showing protein binding inside the fiber: Alexa Fluor 488 images: (a) negative control and (b-d). positive binding of ER protein $(4 \times, 10 \times$ and $20 \times$, respectively).

\section{Discussion}

The most important aspect of this work is to design a sensor with competent immobilization performance to achieve the highest sensitivity of protein detection. The proposed methodology is focused on an array format immuno recognition of $\mathrm{ER} \alpha$ protein using a $\mathrm{HC}$ photonic crystal fiber. The primary step of the experiment is to activate the silica inner core of the fiber to facilitate the detection of ER protein. To attach proteins on a solid surface, the surface of the substrate has to be modified to achieve a maximum binding capacity. ${ }^{28,29}$ Poly (ethylene glycol) derived materials are generally considered to be effective candidates for fabrication of protein-resistant materials. In particular, polycations are found to form stable adsorbed layers on negatively charged oxides, such as silicon dioxide and titanium dioxide. ${ }^{30}$ Kenausis et al. described the surface functionalization method and its importance in the protein resistance. ${ }^{31}$ In their immobilization study, they observed that poly (L-lysine)-g-poly (ethylene glycol) (PLL-gPEG) complex makes polymer combs backbone with the negatively charged metal surface, producing a proteinresistant surface. PLL-g-PEG surface is considered to be a
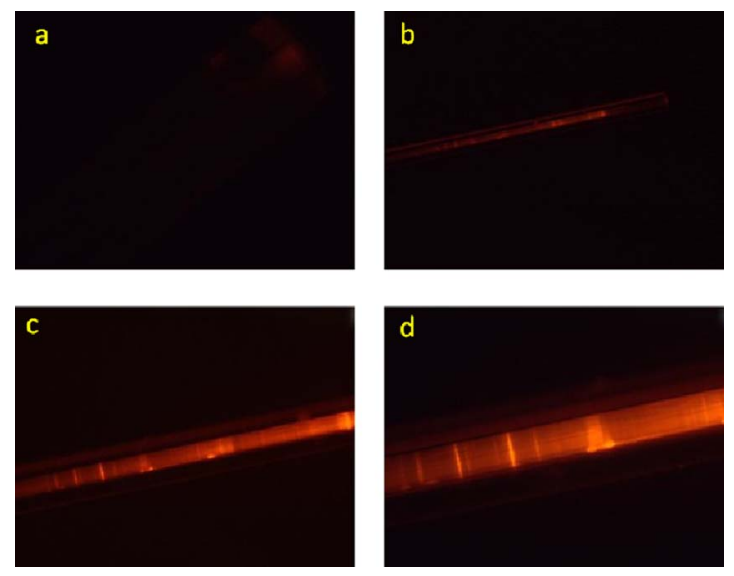

Fig. 6 Fluorescent microscopic images showing protein binding inside the fiber: Alexa Fluor 555 images: (a) negative control and (b-d). positive binding of ER protein $(4 \times, 10 \times$ and $20 \times$, respectively). promising sensor platform for binding $6 \times$ His-tagged proteins and high specificity and quantitative reversibility of the protein was observed. ${ }^{32}$ A biotin-labeled DNA and streptavidin is captured efficiently in PLL and gluteraldehyde coated HC fibers. ${ }^{12}$ PLL showed no interference with the target protein signal because it does not contain intrinsically fluorescent amino acids. ${ }^{33}$ The binding of protein mainly depends on the efficient surface attachment procedures, which is essential for biosensor application. In the work reported in this paper, PLL is used to precoat the inner wall of the fiber to create an activated surface that can bind the targeted protein effectively.

The second step of the sensor construction is very crucial which involves the protein antigen on silica glass fiber in a way that it conserves its characteristics and confirmations. Initially, the $\mathrm{ER} \alpha$ positive (MCF-7) and negative cell (MDAMB-231) lysates are allowed to immobilize inside the core. Second, the primary antibody raised against the ER $\alpha$ protein (antirabbit) is subsequently used to recognize the protein even in fragments, which is available on the inner core surface. Finally, we used the Alexa Fluor 488 goat antirabbit IgG (green fluorescent dye) as a secondary antibody compatible to the anti-ER $\alpha$ protein. We observed under a microscope that the Alexa-488 IgG quenches fluorescence of the fiber core, which confirms the presence of the specific protein, $\operatorname{ER} \alpha$. Concurrently, we have used another secondary antibody Alexa Fluor 555 goat antirabbit $\mathrm{IgG}$ tagged with red fluorescent dye to validate the $\mathrm{ER} \alpha$ protein, and a similar profile was noted, evidencing the specific protein binding.

Recently, few studies have been reported regarding the immobilization and detection of a biomolecule using microstructured optical fibers. Hoiby et al. performed DNA hybridization and specific recognition of antistrepdavidin with streptavidin was observed. ${ }^{34}$ Similarly, fluorescently labeled $\alpha$ streptavidin cy 3 and $\alpha$ CRP-cy 3 were achieved by immobilizing inside the polymer optical fibers by using sample of $27 \mu \mathrm{L} .{ }^{35}$ Ruan et al. achieved a good immobilization and binding of Q dot 800 goat F (ab')2 antimouse IgG conjugate using a $30-\mu \mathrm{L}$ sample in soft glass optical fiber. ${ }^{11}$ Multiple toxic agents, such as ricin $(25 \mathrm{ng} / \mathrm{mL}), \mathrm{F} 1$ antigen from Yersinia pestis $(15 \mathrm{ng} / \mathrm{mL})$, and staphylococcal enterotoxin $\mathrm{B}$ $(5 \mathrm{ng} / \mathrm{mL})$ were detected in a single $150 \mu \mathrm{L}$ sample using planar array immunosensor. ${ }^{36}$ Fiber optic evanescent wave immunosensors have been developed for the detection of toxins, hazardous materials, explosives, and clinical analytes using monoclonal and poly clonal antibodies. ${ }^{37-40}$ Human chorionic gonadotropin was detected through planar waveguide fluorescent immunosensors by sandwich assay using monoclonal antibody. ${ }^{41,42}$ Comparatively, the newly developed assay significantly detect the $\mathrm{ER} \alpha$ protein by direct immuno binding.

In addition, the architecture of this sensor design was strengthened by implementation of strong light sources, precise lenses, and a spectrophotometer to analyze the spectral signatures of the fluorescence images. The emission peaks of green and red dyes were measured at 515 and $585 \mathrm{~nm}$, respectively. This spatial information strongly confirms the specific binding of $\operatorname{ER} \alpha$ protein. It is well understood that the great advantage of the sensor is the capability of analyzing both biological and physical properties of targeted molecules. Though conventional optical fibers are used for immunoas- 


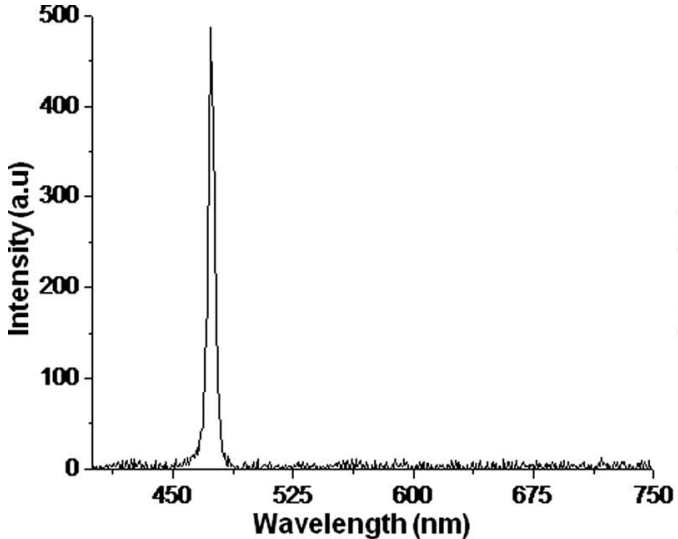

(a)

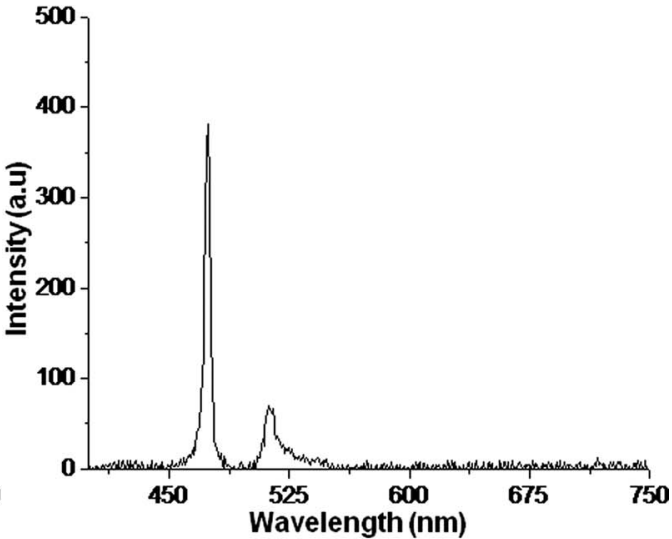

(b)

Fig. 7 Spectral signatures of ER $\alpha$ protein: Alexa Fluor 488 spectrum: (a) negative control and (b) positive binding of ER protein (emission at $515 \mathrm{~nm})$.

says, photonic crystal fibers are more biocompatible and chemically inert because it is made up of pure silica $\left(\mathrm{SiO}_{2}\right)$ without any doping. Here, we describe the potentiality of silicon made, evanescent-based HC photonic crystal fiber as a biosensor for the detection of $\operatorname{ER} \alpha$ protein using specific fluorescent-labeled antibody. The proposed HC-PCF-based biosensors is advantageous over waveguide-based array sensors as a result of the easy light coupling to the sample region. Also, it is possible to change the excitation laser light source more easily by making use of an optical connector. Although we have used an antigen antibody reaction to recognize the $\mathrm{ER} \alpha$ protein, in general, this sensor can be applied to other proteins of interest.

Our experimental data of ELISA method shows that it needs more quantity of samples for the detection, whereas our microstructured fiber optical detection needs very low sample quantity. In comparison to the available techniques, our new method is simple, safer, less expensive, sensitive, and highly specific in assessing the ER status in breast cancer research. This method can be applied for high-throughput biosensor application in biological research and also be used as a diagnostic tool in future translational medicine.

\section{Conclusions}

A biosensing system using a $\mathrm{HC}$ photonic crystal fiber in a total internal reflection configuration for monitoring the fluorescence response of the specific protein is established. We demonstrate an antigen-antibody binding method to detect $\mathrm{ER} \alpha$ protein in an ultrasmall quantity of sample. The recognition of the protein by secondary antibody is visualized by the fluorescent signal (green and red) and measured emission spectrum confirms the presence of $\operatorname{ER} \alpha$ protein. This method involves highly sensitive and simple procedures that can detect $\approx 20 \mathrm{pg}$ of $\mathrm{ER} \alpha$ protein in $50 \mathrm{~nL}$ sample volume. Consequently, the photonic crystal fibers are emerging as potential platforms for biosensing applications in biology and medicine.

\section{Acknowledgments}

The authors acknowledge the financial support received through ASTAR-SERC. One of the authors, V. K. Shinoj, thanks the NTU for a research scholarship award. Dr. Para-

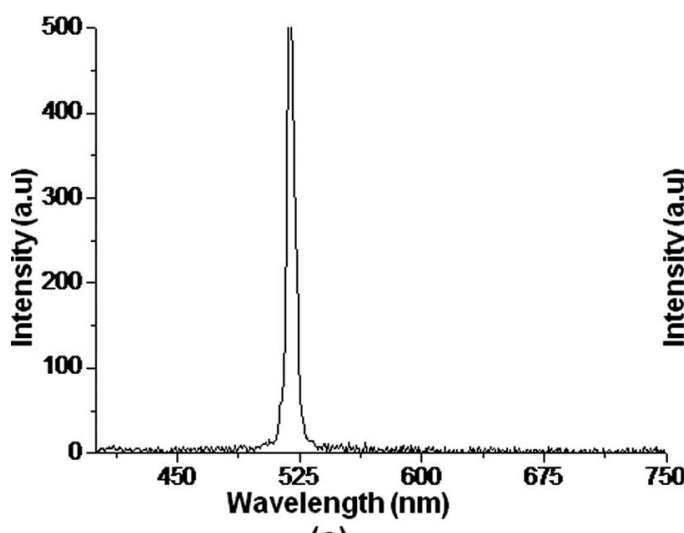

(a)

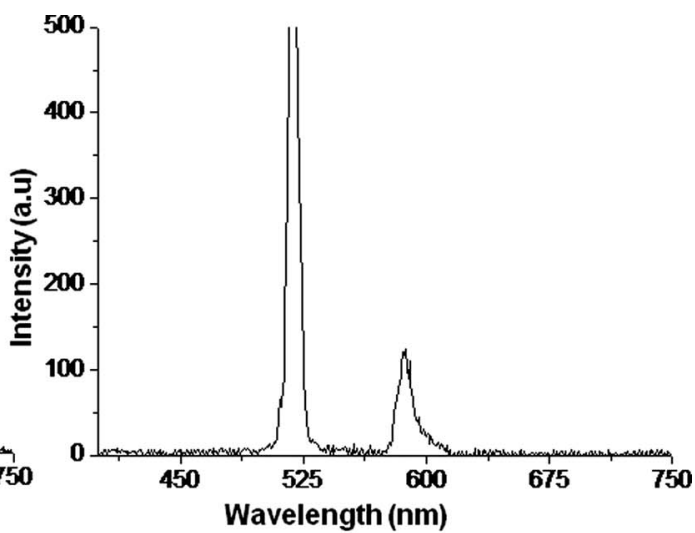

(b)

Fig. 8 Spectral signatures of ER $\alpha$ protein: Alexa Fluor 555 spectrum: (a) negative control and (b) positive binding of ER protein (emission at $585 \mathrm{~nm})$. 
suraman Padmanabhan acknowledges Sir George Radda, A*STAR-BMRC for extending his support toward this collaborative project.

\section{References}

1. E. Phizicky, P. I. H. Bastiaens, H. Zhu, M. Snyder, and S. Fields, "Protein analysis on a proteomic scale," Nature 422(6928), 208-215 (2003).

2. W. Chen, "Nanoparticle fluorescence based technology for biological applications," J. Nanosci. Nanotechnol. 8(3), 1019-1051 (2008).

3. R. Y. Tsien, "The green fluorescent protein," Аппи. Rev. Biochem. 67(1), 509-544 (1998).

4. M. M. C. Cheng, G. Cuda, Y. L. Bunimovich, M. Gaspari, J. R. Heath, H. D. Hill, C. A. Mirkin, A. J. Nijdam, R. Terracciano, T. Thundat, and M. Ferrari, "Nanotechnologies for biomolecular detection and medical diagnostics," Curr. Opin. Chem. Biol. 10(1), 11-19 (2006).

5. X. Fan, I. M. White, S. I. Shopova, H. Zhu, J. D. Suter, and Y. Sun, "Sensitive optical biosensors for unlabeled targets: a review," Anal. Chim. Acta 620(1-2), 8-26 (2008).

6. P. St. J. Russell, "Photonic crystal fibers," Science 299, 358-362 (2003).

7. R. F. Cregan, B. J. Mangan, J. C. Knight, T. A. Birks, P. St. J. Russel, P. J. Roberts, and D. C. Allan, "Single-mode photonic band gap guidance of light in air," Science 285, 1537-1539 (1999).

8. J. A. Ferguson, "A fiber-optic DNA biosensor microarray for the analysis of gene expression," Bio/Technology 14(13), 1681-1684 (1996).

9. J. B. Jensen, L. H. Pedersen, P. E. Hoiby, L. B. Nielsen, T. P. Hansen, J. R. Folkenberg, J. Riishede, D. Noordegraaf, K. Nielsen, A. Carlsen, and A. Bjarklev, "Photonic crystal fiber based evanescentwave sensor for detection of biomolecules in aqueous solutions," Opt. Lett. 29(17), 1974-1976 (2004).

10. M. M. Orosco, "Protein-coated porous-silicon photonic crystals for amplified optical detection of protease activity," Adv. Mater. 18(11), 1393-1396 (2006)

11. Y. Ruan, E. P. Schartner, H. E. Heidepriem, P. Hoggmann, and T. M. Monro, "Detection of quantum-dot labeled proteins using soft glass microstructured optical fibers," Opt. Express 15(26), 17819-17826 (2007).

12. L. Rindorf, "Towards biochips using microstructured optical fiber sensors," Anal. Bioanal. Chem. 385(8), 1370-1375 (2006).

13. N. Skivesen, A. Tetu, M. Kristensen, J. Kjems, L. H. Frandsen, and P. I. Borel, "Photonic-crystal waveguide biosensor," Opt. Express 15(6), 3169-3176 (2007).

14. WHO, "Fact Sheet No. 297: Cancer 2006," Cancer Information Center, USA (2006), http://www.cancer-sos.com/content.php.

15. P. Picard, G. Bunone, J. W. Liu, and O. Donze, "Steroid-independent activation of steroid receptors in mammalian and yeast cells in breast cancer," Biochem. Soc. Trans. 25, 597-602 (1997).

16. V. J. Elwood, "Steroid hormones, receptors, and antagonists," Ann. N.Y. Acad. Sci. 784, 1-17 (1996).

17. D. R. J. Snead, "Methodology of immunohistological detection of oestrogen receptor in human breast carcinoma in formalin-fixed, paraffin-embedded tissue: A comparison with frozen section methodology," Histopathology 23(3), 233-238 (1993).

18. S. M. Thorpe, "Prognostic value of steroid hormone receptors: Multivariate analysis of systemically untreated patients with node negative primary breast cancer," Cancer Res. 47(22), 6126-6133 (1987).

19. A. P. F. Turner, "Biosensors—-sense and sensitivity," Science 290(5495), 1315-1317 (2000).

20. T. Vo-Dinh, "Biosensors and biochips: advances in biological and medical diagnostics," J. Anal. Chem. USSR 366(6-7), 540-551 (2000).

21. R. I. Stefan, "Immunosensors in clinical analysis," J. Anal. Chem. USSR 366(6-7), 659-668 (2000).

22. H. J. Geerligs, "The influence of $\mathrm{pH}$ and ionic strength on the coating of peptides of herpes simplex virus type 1 in an enzyme-linked im- munosorbent assay," J. Immunol. Methods 106(2), 239-244 (1988).

23. J. Yang, H. Wang, Y. Jiang, Y. Sun, K. Pan, H. Lei, Q. Wu, Y. Shen, Z. Xiao, and Z. Xu, "Development of an enzyme-linked immunosorbent assay (ELISA) method for carbofuran residues," Molecules 13(4), 871-881 (2008)

24. Y. Chien, M. Ito, Y. Park, T. Tagami, B. D. Gehm, and J. L. Jamsen, "A fusion protein of the estrogen receptor (ER) and nuclear receptor corepressor (NCoR) strongly inhibits estrogen-dependent responses in breast cancer cells," Mol. Endocrinol. 13(12), 2122-2136 (1999).

25. J. M. Harvey, G. M. Clark, C. K. Osborne, and D. C. Alfred, "Estrogen receptor status by immunohistochemistry is superior to the ligand-binding assay for predicting response to adjuvant endocrine therapy in breast cancer," J. Clin. Oncol. 17(5), 1474-1481 (1999).

26. H. Gobbi, "Predictive factors of breast cancer evaluated by immunohistochemistry," J. Brasil. Patologia Med. Lab. 44(2), 131-140 (2008).

27. M. M. Bradford, "A rapid and sensitive method for the quantitation of microgram quantities of protein utilizing the principle of protein-dye binding," Anal. Biochem. 72(1-2), 248-254 (1976).

28. H. Zhu and M. Snyder, "Protein arrays and microarrays," Curr. Opin. Chem. Biol. 5(1), 40-45 (2001).

29. H. Zhu and M. Snyder, "Protein chip technology," Curr. Opin. Chem. Biol. 7(1), 55-63 (2003).

30. S. Morgenthaler, C. Zink, B. Stadler, J. Voros, S. Lee, N. D. Spencer, and S. G. P. Tosatti, "Poly(L-lysine)-grafted-poly(ethylene glycol)based surface-chemical gradients: preparation, characterization, and first applications," BioInterphases 1(4), 156-165 (2006).

31. G. L. Kenausis, J. Vörös, D. L. Elbert, N. Huang, R. Hofer, L. R. Taylor, M. Textor, J. A. Hubbell, and N. D. Spencer, "Poly(1-lysine)g-poly(ethylene glycol) layers on metal oxide surfaces: attachment mechanism and effects of polymer architecture on resistance to protein adsorption," J. Chem. Phys. 104(14), 3298-3309 (2000).

32. G. Zhen, S. Zurcher, D. Falconet, F. Xu, E. Kuennemann, and M. Textor, "NTA-functionalized poly(L-lysine)-g-poly(ethelyene glycol): A polymeric interface for binding and studying 6 His-tagged protiens," in 27th IEEE Int. Conf. on Engineering in Medicine and Biology Society (IEEE-EMBS), pp. 1036-1038 (2005).

33. G. MacBeath and S. L. Schreiber, "Printing proteins as microarrays for high-throughput function determination," Science 289(5485), 1760-1763 (2000)

34. P. E. Hoiby, L. B. Nielsen, J. B. Jensen, T. P. Hansen, A. Bjarklev, and L. H. Pedersen, "Molecular immobilization and detection in a photonic crystal fiber," in Proc. SPIE 5317, 220-223 (2004).

35. J. B. Jensen, P. E. Hoiby, G. Emiliyanov, O. Bang, L. H. Pedersen, and A. Bjarklev, "Selective detection of antibodies in microstructure polymer optical fibers," Opt. Express 13(5), 5883-5889 (2005).

36. R. M. Wadkins, J. P. Golden, L. M. Pritsiolas, and F. S. Ligler, "Detection of multiple toxic agents using a planar array immunosensor," Biosens. Bioelectron. 13(3-4), 407-415 (1998).

37. R. A. Ogert, J. E. Brown, B. R. Singh, L. C. Shriver-Lake, and F. S. Ligler, "Detection of Clostridium botulinum toxin A using a fiber optic-based biosensor," Anal. Biochem. 205, 306-312 (1992).

38. F. S. Ligler, J. P. Golden, L. C. Shriver-Lake, D. Wijesuria, R. A. Ogert, J. E. Brown, and G. P. Anderson, "Fiber-optic biosensor for the detection of hazardous materials," Immunomethods 3, 122-127 (1993).

39. U. Narang, P. R. Gauger, A. W. Kusterbeck, and F. S. Ligler, "Multianalyte detection using a capillary-based flow immunosensor," Anal. Biochem. 255, 13-19 (1998).

40. C. A. Rowe, S. B. Scruggs, M. J. Feldstein, J. P. Golden, and F. S. Ligler, "An array immuno sensor for simultaneous detection of clinical analysis," Anal. Chem. 71, 433-439 (1999).

41. J. N. Herron, K. D. Caldwell, D. A. Christensen, S. Dyer, V. Hlady, P. Huang, V. Janatova, H. K. Wang, and A. P. Wei, "Fluorescent immunosensors using planar waveguides," Proc. SPIE 1885, 28-39 (1993).

42. D. A. Christensen, S. Dyer, D. Fowers, and J. N. Herron, "Analysis of excitation and collection geometries for planar waveguide immunosensors," Proc. SPIE 1886, 2-8 (1993). 